\title{
Viewboard Effectiveness on Raharja Internet Cafe Website as Sales Information Submission Media
}

\author{
Tuti Nurhaeni ${ }^{1}$, Karl Werhan ${ }^{2}$, Marviola Hardini ${ }^{3}$ \\ ${ }^{1,3}$ Raharja University, Jl. Jendral Sudirman No.40 Modernland, Cikokol, Tangerang \\ ${ }^{2}$ University College Dublin \\ e-mail: tuti@raharja.info, karlwhelan4@gmail.com, marviola@raharja.info
}

To cite this document:

Nurhaeni, T., Werhan, K., \& Hardini, M. (2019). Viewboard Effectiveness on Raharja Internet Cafe Website as Sales Information Submission Media. Aptisi Transactions On Technopreneurship (ATT), 1(1), 20-26.

Retrieved from https://pandawan.aptisi.or.id/index.php/att/article/view/20

\begin{abstract}
Information is a key to success in communicating. Communication will not be possible without information. But if the information we convey is wrong it will cause a problem. At Raharja University there is a facility that provides needs services to students such as searching for material, printing, scans, and binding documents, there are also accessories and service places if there are students who have problems with the equipment given for study, Raharja Internet Cafe. Raharja Internet Cafe has a website to be used by students who want to order their needs. However, the admin who maintains Raharja Internet Cafe cannot monitor what products or goods are the best-selling or the most sold because they are not well monitored. With no monitoring of the admin sales process or the guard cannot report the goods to the University, or the conventional data recording process. These problems are certainly considered ineffective because Raharja University is engaged in technology in each of its lecture activities. Creating a viewboard on the Raharja Internet Cafe website as a medium for delivering sales information is the solution. The method that I use is a method of data collection namely observation and literature study and a qualitative approach. The results of this study are that the presence of a viewboard on the Raharja Internet Cafe website can facilitate the admin or guard of Raharja Internet Cafe to make a report to the Raharja University.
\end{abstract}

Keywords: Effectiveness, Viewboard, Raharja Internet Cafe, Information

\section{Introduction}

Information is a very important thing in communication because there is a data set to be delivered both to each individual and to several individuals directly. Quoted from a journal made by Eko Nugroho (2018) Information is an important asset for organizations in their information technology services. According to Sihotang in 2018 Information is data that has been processed into a form that is more useful for those who receive it. From the two meanings above, it can be interpreted that information is an important key that can be useful for along with the development of technology in the current digital era, the delivery of information has a very important role for top level management to help make decisions. At this time, the use of dashboards / viewboards has begun to be used as a medium to convey information to a system in presenting information, so that users can make decisions easily.

According to Saeful (2018) Dashboard is an application that in real time will monitor various information needed by an organization or company in various formats. whereas according to Randy Wijaya I n 2018 the viewboard is a custom application that plays an important role in displaying the information needed. As well as quoted from a journal written by Kevin et al in 2018 Viewboard or one category of business intelligence applications that in real time will 
monitor various information needed by an organization or company with various formats such as graphical gadgets, typically, gauges, charts, indicators, and color-coded maps that allow them to make smart decisions quickly. Can the authors conclude Viewboard or Dashboard is a tool to convey information to users in order to make decisions quickly and precisely.

So it is expected that with the viewboard on the Raharja Internet Cafe website the process of delivering information can be more effective to top level management of Raharja University.

\section{Research Method}

This study uses data collection research methods to obtain the data needed for the purposes of this study. The researcher made observations to the field to see directly what the problems were. By going down to the field to see the problems faced makes it easier for researchers to solve problems, because the data obtained is real and not fictitious. Not only are the methods that researchers use, researchers also approach qualitatively by describing in depth the facts or data obtained when making observations. This approach is used because this study aims to explain data or facts from existing conditions. This research also analyzes various things that must be done to achieve a predetermined condition in the future.

In this study the author will explain or describe the effectiveness of using the viewboard on a Raharja Internet Cafe website at Raharja University as a medium for delivering sales information to top level management, which this has been implemented. With this research, it is expected that the viewboard or dashboard system on the Raharja Internet Cafe website can be more modern and easy to read by users so that the information delivered can be received well. The author has also conducted a literature study that is looking for similar research on the viewboard to assist the author in conducting this research. Here are some of the literature reviews that the authors collected:

1. The research conducted by Randi Wijaya in 2018 with the title "Implementation of Viewboard Technomedia Journal using the iLearning Journal Center system at Higher Education" this study discusses the TMJ Viewboard as a place of service information from existing data and related to writing scientific papers or journals so that later it will display valid information, it can also be easily monitored using computer-based, this makes it easy for the admin to manage the data contained in the TMJ into a Viewboard

2. Research conducted by by Kevin Rama Putra (2018 with the title "Implementation of Viewboard as Information Session for Thesis Session at PESSTA + in Higher Education". In this study needed a means to provide solutions, evaluate the process and monitor the performance of the ongoing process. expected to provide an overview of information regarding the thesis trial / final project activities of PESSTA +.

3. The research entitled "Implementation of Yii Framework-Based Viewboard Validation Status at STATUS + in Higher Education" by Yoyo Syoifana et al (2017). This research aims to make it easier for students to complete 10 points of objective assessment. There needs to be data to describe the performance with the presence of Viewboard, it is expected to be able to solve existing problems, namely to provide information about student performance on the objective assessment validation status in the PESSTA + system.

4. Research in 2018 with the title "Implementation of Bootstrap-Based Viewboard Rooster as a Support for iDuhelp Service! In Higher Education "conducted by Fauziyyah et al. This study discusses the ROOSTER viewboard sometimes not in accordance with the data contained in the ROOSTER system itself. This certainly makes the customer or admin unable to see the ROOSTER ticket status that has been made accurately because of lack of updates. Likewise with the boss or the leader it is difficult to check the performance of the ROOSTER staff. Therefore this study aims to develop a ROOSTER system Viewboard.

ATT Vol.1, No. 1 March $2019: 20-26$ 
5. The research conducted by Ely Susanti (2016) with the title "IMPLEMENTATION OF VIEWBOARD IN SUPPORTING INFORMATION SPREAD WITH PRESENTATION OF ARTIFICIAL INFORMATICS IN HIGHER EDUCATION". This study discusses the Viewboard Application that has been tested to measure statistics on student overview on Raharja College as a place of development and Viewboard research is conducted. The final results show that Viewboard can draw processed data from various existing database repositories and display critical information by presenting the characteristics of Artificial Informatics.

6. The study entitled "Implementation of Yiboard-Based Viewboard GO + as Media for Monitoring Student Payments" conducted by Ika Amalia in 2016. This study discusses the GO + viewboard as a place and container of information from data in the GO + database so that later it will display accurate information and the latest relating to student payments. With this viewboard goal, it can also make it easier for staff to monitor student data

7. The research conducted by Maya Ima Erviani (2016) entitled "OPTIMIZATION OF RHJFOX VIEWBOARD BASED ON BOOTSTRAP AS A DECISION SUPPORT SYSTEM". This study discusses the existence of the RhjFox viewboard can inform you about the data in the RhjFox database so that it becomes a support decision that will later display accurate and up-to-date information relating to the subject of RhjFox.

8. The research conducted by Maya Ima Erviani (2016) entitled "OPTIMIZATION OF RHJFOX VIEWBOARD BASED ON BOOTSTRAP AS A DECISION SUPPORT SYSTEM". This study discusses the existence of the RhjFox viewboard can inform you about the data in the RhjFox database so that it becomes a support decision that will later display accurate and up-to-date information relating to the subject of RhjFox.

9. Subsequent research was conducted in 2019 by Aulia Yolandari entitled "Informative Viewboard Implementation at the Association of Indonesian Private Universities in the Industrial Era 4.0". this study discusses the dissemination of information about education and communication media such as the APTISI website carried out up to date and summarized in the viewboard. problem solving in this system is a viewboard-based information system on an official site that is used as a place or container and the dissemination of information specifically for its members and can display activities owned by organizations and institutions.

\section{Findings}

\subsection{Problem}

The process of delivering previous sales information that still uses conventional methods, so that the delivery process is classified as very less effective. As the rapid development of information technology makes conventional methods increasingly lagging with the times. All activities in daily life are now using technology because it is proven to be easier, efficient and effective in its use.

At present the University of Raharja has used technology in its lecture activities both starting from the assessment, delivery of information and others. It will look uncomfortable if the delivery of sales information at Raharja Internet Cafe which is a student service facility still uses conventional methods.

Therefore, a website is currently available on Raharja Internet Cafe as a medium for ordering student goods. On the website there is also a viewboard that displays information on the sale of items that are most often ordered by students. So that the admin does not need to bother using the conventional method of recording using paper again to make a report to the top level management.

\subsection{Research}

From the problems described earlier, a problem solving is needed as a solution. On the Raharja Internet Cafe website there is a viewboard that explains sales information. 
There are $\mathbf{4}$ graphs that have been applied to the Raharja Internet Cafe Website including daily to annual sales information.

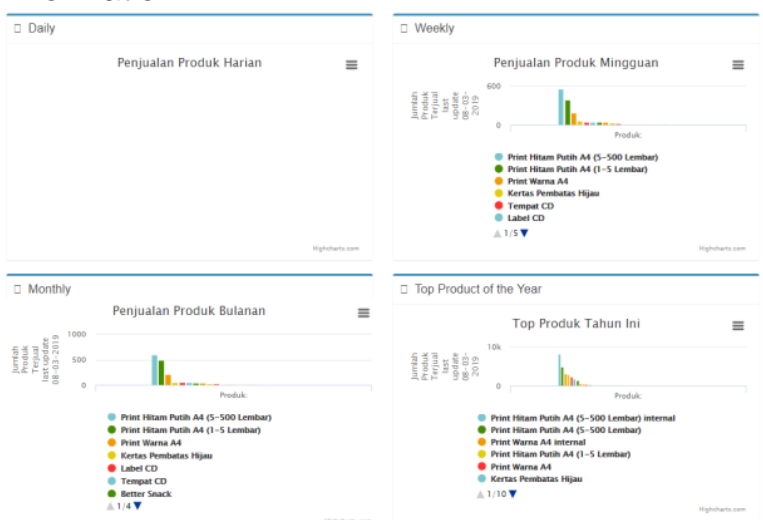

Figure 1. Viewboard of the RIC website

From the graph contained in the viewboard, the admin can see information on sales needs that are often purchased by students.

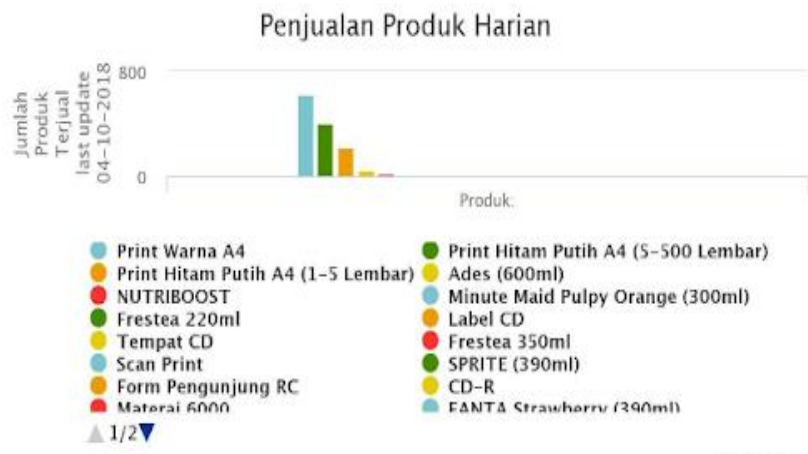

Figure 2. Daily Sales Chart

From the picture above there is information on the sale of goods that are needed by students for a full day.

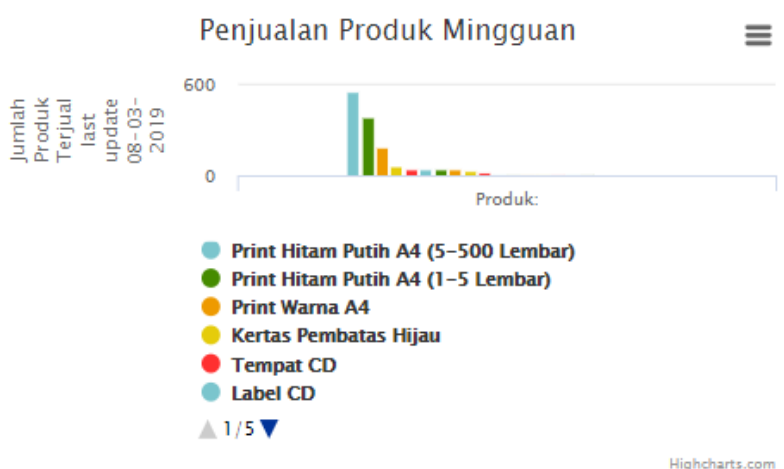

Figure 3. Weekly Sales Chart

From the picture you can see what items are best-selling for students to buy for the past 1 week. 


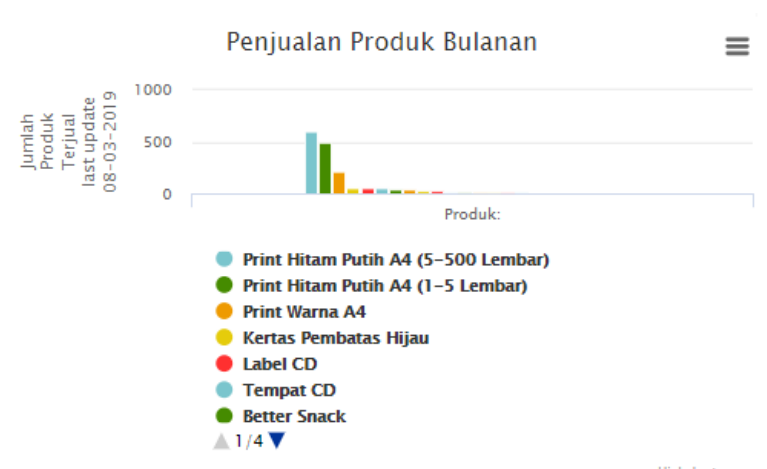

Figure 4 Monthly Sales Chart

From the picture can be taken an information item that is most often ordered by students to meet their needs for 1 month.

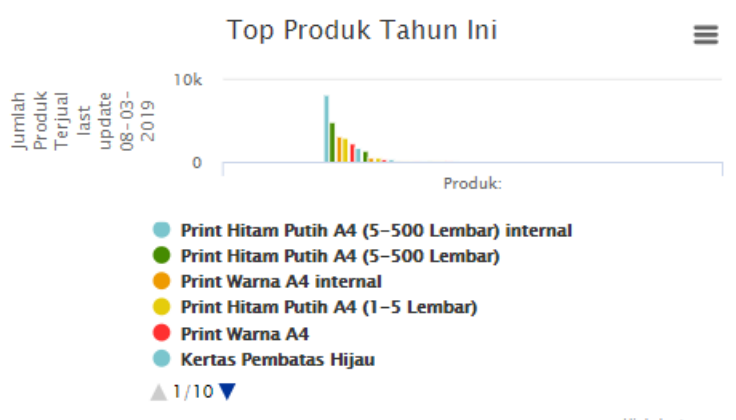

\section{Figure 5 Annual Sales Graph}

The graph in the picture above can provide information in the form of the bestselling products ordered by students during lecture activities. From some of the products provided by Raharja Internet Cafe to support lecture activities, it turns out that students most often order to print or print lecture files in black and white.

With the information that is very informative, the admin can easily report it to the Raharja University as the service provider. Admin also does not need to record reports using paper media because it can be seen on the Raharja Internet Cafe Website.

\section{Conclusion}

By having a viewboard on the Raharja Internet Cafe website that is useful for conveying information about sales reports to Raharja University's Top level management, the author can draw conclusions such as the following: The Viewboard on the Raharja Internet Cafe website can make it easier for the admin to report sales to the campus. The viewboard on the Raharja Internet Cafe website has proven effective in conveying sales information made by the admin to top level management. Submission of information that is easily understood by users makes the function a viewboard more useful, namely to convey information from existing data to users. Thus, the communication process to top level management becomes more effective and efficient of course. In a study, of course, it has limitations and what can be done in the future if current research runs smoothly. So the disadvantage of this study is to convey information still using 1 graph, meaning the author feels that there is still very little information delivered, although it is very informative but there are still shortcomings in the system such as the colors of some products are still the same in some products and graphics presented is still lacking. The author hopes that if the research continues, the viewboard can be further multiplied so that the process of delivering information can be more effective than before. 
References

[1] Rahardja, U., Handayani, I., \& Wijaya, R. (2018). Penerapan Viewboard Technomedia Journal menggunakan sistem iLearning Journal Center pada Perguruan Tinggi. Technomedia Journal, 2(2), 81-93.

[2] Handayani, I., Febriyanto, E., \& Solichin, K. R. P. (2018). Penerapan Viewboard Sebagai Media Informasi Sidang Skripsi Pada PESSTA+ di Perguruan Tinggi. Technomedia Journal, 2(2), 55-65.

[3] Rahardja, U., Handayani, I., \& Setiani, L. (2017). Viewboard Sebagai Laporan Jumlah Keseluruhan Artikel Pada iLearning Raharja Ask and News. CogITo Smart Journal, 3(1), 42-55.

[4] Rahardja, U., Pratama, D., \& Susanti, E. (2016). Implementasi Viewboard Dalam Mendukung Penyebaran Informasi Dengan Penyajian Artificial Informatics Pada Perguruan Tinggi. CCIT Journal, 9(03), 251-257.

[5] Rahardja, U., Handayani, I., \& Syoifana, Y. (2019). Penerapan Viewboard Status Validasi Berbasis Yii Framework Pada PESSTA+ Di Perguruan Tinggi. Creative Information Technology Journal, 4(4), 297-305.

[6] Aini, Q., Alwiyah, A., \& Putri, D. M. (2019). Effectiveness of Installment Payment Management Using Recurring Scheduling to Cashier Performance. Aptisi Transactions On Management, 3(1), 13-21.

[7] Febriyanto, E., Yulianto, F. H. N. L., \& LESTARI, F. H. N. (2018). Penerapan Viewboard Rooster Berbasis Bootstrap Sebagai Penunjang Pelayanan iDuhelp! Pada Perguruan Tinggi. Jurnal IImiah Teknologi Informasi Asia, 12(2).

[8] Rahardja, U., Tiara, K., \& Erviani, M. I. (2016). Optimalisasi Viewboard Rhjfox Berbasis Bootstrap sebagai Sistem Penunjang Keputusan. Technomedia Journal, 1(1), 50-64.

[9] Rahardja, U., Lutfiani, N., \& Yolandari, A. (2019). Penerapan Viewboard Informatif Pada Asosiasi Perguruan Tinggi Swasta Indonesia Dalam Era Industri 4.0. Technomedia Journal, 3(2), 224-234.

[10] Rahardja, U., Aini, Q., \& Khoirunisa, A. (2017). Implementasi Business Intelligence Menggunakan Highchart pada Sistem Penilaian Absensi berbasis YII Framework. CSRID (Computer Science Research and Its Development Journal), 9(2), 115-124.

[11] Rahardja, U., Aini, Q., \& Khoirunisa, A. (2019). Monitoring Kinerja User Akuntan Menggunakan Dashboard Pada Web Based Accounting Online di Perguruan Tinggi. SATIN-Sains dan Teknologi Informasi, 4(2), 58-62.

[12] Rahardja, U., Aini, Q., Ariessanti, H. D., \& Khoirunisa, A. (2018). Pengaruh Gamifikasi pada iDu (iLearning Education) dalam Meningkatkan Motivasi Belajar Mahasiswa. Nusantara Journal of Computers and its Applications, 3(2).

[13] Rahardja, U., Aini, Q., Apriani, D., \& Khoirunisa, A. (2019). Optimalisasi Informasi Manajemen Laporan Assignment Pada Website Berbasis Content Management System. Technomedia Journal, 3(2), 213-223.

[14] Aini, Q., Dhaniarti, I., \& Khoirunisa, A. (2019). Effects of iLearning Media on Student Learning Motivation. Aptisi Transactions on Management (ATM), 3(1), 1-12.

[15] Rahardja, U., Aini, Q., \& Khoirunisa, A. (2018). Effect of iDu (iLearning Education) on Lecturer Performance in the Lecture Process. Aptisi Transactions on Management (ATM), 2(2), 140-148.

[16] Rahardja, U., Aini, Q., \& Khoirunisa, A. (2018). The Effect of Rinfogroups as a Discussion Media in Student Learning Motivation. Aptisi Transactions on Management (ATM), 2(1), 79-88.

[17] Moeins, A., Sudaryono, S., \& Khoirunisa, A. (2018). Utilization of Management of Writing Scientific in the Learning Process in Higher Education. Aptisi Transactions on Management (ATM), 2(1), 1-8.

[18] Febriyanto, E., Handayani, I., \& Suprayogi, D. (2019). Aplikasi Sistem Penilaian Penguji Berbasis YII Framework Sebagai Media Input Nilai Mahasiswa Sidang Tugas Akhir Dan Skripsi Pada Perguruan Tinggi. CSRID (Computer Science Research and Its Development Journal), 10(2), 111-123.

[19] Ariessanti, H. D., Martono, A., \& Suprayogi, D. (2019). SISTEM INFORMASI PROFIL MAHASISWA PADA PENILAIAN PENGUJI PESSTA+ DI PERGURUAN TINGGI. CERITA Journal, 5(1), 76-88. 
[20] Kamil, M., Rianto, J., \& Suprayogi, D. (2019). Management of Deciding Decision Making Final Project Advisor in Optimizing Learning. Aptisi Transactions on Management (ATM), 2(2), 168-176.

[21] Rahardja, U., Aini, Q., \& Santoso, N. P. L. (2018). Pengintegrasian YII Framework Berbasis API pada Sistem Penilaian Absensi. SISFOTENIKA, 8(2), 140-152.

[22] Rahardja, U., Aini, Q., Azizah, N., \& Santoso, N. P. L. (2018). Efektivitas Akuntansi Online dalam Menunjang Proses Rekonsiliasi. Nusantara Journal of Computers and its Applications, 3(2).

[23] Aini, Q., Rahardja, U., Arribathi, A. H., \& Santoso, N. P. L. (2019). Penerapan Cloud Accounting dalam Menunjang Efektivitas Laporan Neraca pada Perguruan Tinggi. CESS (Journal of Computer Engineering, Science and System), 4(1), 60-64.

[24] Sudaryono, S., Rahardja, U., \& Apriani, D. (2019). The CICES Journal Governance Performance Improvement on Quality of Current Issues (Case Study of STMIK RAHARJA). Aptisi Transactions On Management, 3(1), 57-64.

[25] Febriyanto, E., Rahardja, U., Faturahman, A., \& Lutfiani, N. (2019). Sistem Verifikasi Sertifikat menggunakan Digital Image Processing pada Central Event Information. Techno. Com, 18(1), 50-63.

[26] Rahardja, U., Lutfiani, N., Lestari, A. D., \& Manurung, E. B. P. (2019). Inovasi Perguruan Tinggi Raharja Dalam Era Disruptif Menggunakan Metodologi iLearning. Jurnal IImiah Teknologi Informasi Asia, 13(1), 23-34.

[27] Febriyanto, E., \& Rahardja, U. (2019). Penerapan Midtrans sebagai Sistem Verifikasi Pembayaran pada Website iPanda. Jurnal Informatika Upgris, 4(2).

[28] Harahap, E. P., Rahardja, U., \& Salamuddin, M. (2019). Aplikasi Panduan dan Pembayaran Tiket Masuk Mendaki Gunung Menggunakan Metodologi Sistem Multimedia Luther-Sutopo. SATIN-Sains dan Teknologi Informasi, 4(2), 9-16. 